\title{
An Analysis of Authentic Assessment Implementation Based on Curriculum 2013 in SMP Negeri 4 Singaraja
}

\author{
Kadek Agus Suarimbawa1, ${ }^{*}$, A. A. I. N. Marhaeni' ${ }^{2}$, G. A. P. Suprianti ${ }^{3}$ \\ ${ }^{1}$ English Departement. Universitas Pendidikan Ganesha, Indonesia \\ ${ }^{2}$ English Departement. Universitas Pendidikan Ganesha, Indonesia \\ ${ }^{3}$ English Departement. Universitas Pendidikan Ganesha, Indonesia
}

\begin{abstract}
This research aimed at (1) describing authentic assessment preparation according to Curriculum 2013 by grade seven teachers in SMP Negeri 4 Singaraja, (2) describing authentic assessment implementation according to Curriculum 2013 (3) describing obstacles experienced by teachers in implementing authentic assessment according to Curriculum 2013 This research is descriptive qualitative study. The data were gaining by study documents, observations, and interview. The result shows that (1) the conformity of authentic assessment preparation based on Curriculum 2013 by the teachers in is $53.97 \%$ which category is sufficient. (2) Conformity of authentic assessment implementations by the teachers is $44.4 \%$ which category is sufficient. (3) Obstacles experienced by teachers are in terms of students' number and lack of time in the authentic assessments implementation. In conclusion, authentic assessments implementation already measured the competence of knowledge, attitudes and skills of the students according to Curriculum 2013.
\end{abstract}

Keywords:

Authentic assessment,

Implementation,

Obstacles,

Preparation

\section{Introduction}

Curriculum 2013, which is applied at this time is expected to answer the constantly changing challenges of the time which cannot be prevented, and to prepare learners who are able to compete in the future with all the advances in science and technology. Changes in the KTSP curriculum into the Curriculum 2013 caused alteration of paradigm in the learning process, in which every learning activity is expected to shape the attitudes and behavior of the students. The curriculum changes have implications for how teachers teach in the learning process using a scientific approach. Curriculum changes also have implications to assessment.

Authentic assessment in Curriculum 2013 is expected to assess three aspects of the students which are attitude, knowledge, and skill. Authentic assessment is an evaluation process that involves various forms of measurement that reflects the performance of student learning, achievement, motivation, and attitudes on relevant activities in learning (American Librabry Association, In Syofiana, 2010). Gulikers (in Idham, Nadrun, Darmawan, 2015) mentions that the authenticity of assessment involves authentic task, physical context, social context, assessment result, and assessment criteria. Authentic tasks are the tasks that reflect professional activities. The tasks must be relevant to the students' need that reflects professional activities. Physical context refers to the time and condition. Conducting the assessment should be in appropriate time in order to improve students' ability in using their knowledge in the real-life situation. Social context refers to assessment that considers suitability of the culture and community where the students live. Assessment result is the outcome of students' work in the assessment process. The assessment result should be real and useful for the students' life. Assessment criteria are the characteristic of students' performance. It is used to score the students' performance in order to stimulate them to learn.

Designing authentic assessment must be planned well in learning preparation. It must follow some systematic steps. According to Mueller (2005), the steps of designing authentic assessment are to determine standard, to choose authentic task, to determine criteria of students' performance, and to make scoring rubric. Teachers must follow those systematic processes. They must choose the authentic task based on the standard of what students should know and be able to do, then make criteria of students'

* Corresponding author.

E-mail Address: suarimbawajoes@gmail.com (Kadek Agus Suarimbawa), ngurah_marhaeni@yahoo.com (A. A. I. N. Marhaeni),

gap.undiksha@undiksha.ac.id (G. A. P. Suprianti) 
performance in authentic task, and finally make the scoring rubric based on the criteria of students' performance.

However, authentic assessment requires teachers to have proper understanding and commitment to use, because it needs an intensive preparation and procedures to be applied effectively (Fatonah, Suyata, Prasetyo, 2013) In this case, teachers play a significant role as the assessors who are supposed to master how to assess their students well. In contrast, the real condition shows that some teachers are not familiar enough with some techniques in authentic assessment such as self-peer assessment, project based assessment and portfolio (Chan, 2006; Oz, 2014 in Aliningsih \& Sofwan, 2015). Consequently, without adequate and proper knowledge and skills, some problems will almost certainly appear among teachers who apply the assessment.

Learning preparation is done by constructing lesson plan (RPP) which is developed in detail referring to the syllabus, textbooks, and teacher guide's book. Nesari \& Heidari (2014) stated that lesson planning is an important process by teachers in gaining experience since it forces them to reflect on what to teach, how to teach and how to evaluate. The lesson plan can be developed by teachers in groups between schools or between regions which is coordinated, facilitated and supervised by education departments or ministries of the local religion. (Peraturan Menteri Pendidikan dan Kebudayaan No. 103 Tahun 2014). Besides, in Peraturan Menteri Pendidikan dan Kebudayaan No. 103 Tahun 2014 also describes the development of learning assessment means to determine the scope, techniques, and instruments, as well as create scoring guidelines. In addition, the lesson plan also include the proposed program of providing positive feedback, reinforcement, enrichment and remedial.

In Curriculum 2013, based on Peraturan Menteri Pendidikan dan Kebudayaan No. 65 Tahun 2013, there are three main aspects assessed using authentic assessment, which are attitude, knowledge, and skill. Techniques and instruments used for the authentic assessment of the competence of attitudes, knowledge, and skills are further described in Peraturan Menteri Pendidikan dan Kebudayaan No. 104 Tahun 2014 about Assessment of Learning Outcomes by Educator on Primary Education and Secondary Education as follows.

A. Attitude Competency Assessment

Educators assess attitude competence through observation, self-assessment, peer-assessment by learners, and journals. The instrument used for observation, self-assessment, and assessment of learners among participants is a check list or the assessment scale (rating scale), accompanied by rubric, whereas in journals such as notes educators.

B. Knowledge Competence Assessment

Educators assess the competence of knowledge through written tests, observation, and worksheet. Written test instrument is in the form of multiple choice questions, stuffing, short answer, true-false, matching, and description. Observation is done through discussion, question and answer, and conversation in the classroom activities. Worksheet is the form of homework assignments or projects done individually or in groups according to the characteristics of the task.

C. Skills Competency Assessment

Educators assess competency skills require learners to demonstrate a certain competence by using performance, project, product, portfolio, and written assessments. Instruments used in the form of a check list or the assessment scale (rating scale) incorporating sections. Performance is a practice that requires a response in the form of assessment skills of an activity or behavior in accordance with the demands of competence. Projects is learning tasks which include the design, implementation, and reporting in writing or orally in a certain time. Product assessment includes the ability of learners to make the products, technology, and art, such as: food, clothing, sanitary facilities, technological tools, works of art, and goods made of fabric, wood, ceramic, plastic, or metal. Portfolio assessment is the assessment carried out by assessing the entire collection of works of students in certain fields that are reflective-integrative to know the interests, growth, achievement, and / or creativity of learners within a certain time. The work can be shaped concrete actions that reflect concern for the learner to the environment. In addition to assess the competence of knowledge, a written assessment is also used to assess the competence of skills, such as essay writing, report writing, and writing letters.

Based on previous explanation about the importance of authentic assessment, the teachers in SMP Negeri 4 Singaraja should use authentic assessment as their assessment method based on the Curriculum 2013 which is applied in this school in academic years 2016/2017. Curriculum changes from KTSP to the Curriculum 2013 certainly require preparation. Teachers have some problems in implementing the authentic assessments in teaching using Curriculum 2013. The problems are caused by different process of assessing using authentic assessment in Curriculum 2013 and using standard 
assessment in curriculum KTSP. In standard assessment, teachers only need to assess final result of students' competency without concerning the process to reach the competency. However, in using the authentic assessment, teachers have to assess the students' competency from the preparation, the process, until the result of the learning.

This study was conducted to provide an overview of teachers' authentic assessment implementation in learning. Through this research, the researcher focused on analyzing the preparation, the implementation, and the obstacle in the implementation of authentic assessment used by the teachers of grade seven in English teaching in SMP Negeri 4 Singaraja based on the Curriculum 2013.

\section{Method}

This research used descriptive qualitative research method. According to Miles and Huberman (1994), qualitative research is conducted through an intense contact with real life situation. The situations are typically 'banal' means that it is a normal situation without any control; reflect to daily life of individuals, groups, societies, and organization. Sampling the source of data was done by using purposive sampling, with triangulation of data collection techniques (combined), data analysis is inductive or qualitative, and the results of qualitative research emphasizes on meaning rather than generalization.

The research was conducted in SMP Negeri 4 Singaraja. Choosing SMP Negeri 4 Singaraja as a research field is based on the consideration that SMP Negeri 4 Singaraja is one of favorite schools in Singaraja and the school has already applied Curriculum 2013 which means the school has to use authentic assessment in the learning process. Subjects in this study are teachers of grade seven in SMP Negeri 4 Singaraja who are expected to provide the necessary information about object of the research. The object of this study is the preparation, implementation, and obstacles experienced by the grade seven teachers in SMP Negeri 4 Singaraja who are implementing authentic assessment in teaching English according to the Curriculum 2013.

There were three types of data collection namely, document analysis, observation, and interview. Method of data collection conducted in this research is called as triangulation of data. The benefits of triangulation is to increase the confidence of research, creating innovative ways to understand the phenomenon, the findings reveal the unique, challenging or integrate theory and gives a clearer understanding of the problem (Miles and Huberman, 1994).

According to Miles and Huberman (1994), qualitative data analysis techniques were classified as three concurrent flows of activity: data reduction, data display, and conclusion drawing/verification. Data reduction is process of selecting, focusing, simplifying, abstracting, and transforming the data that appear in written-up field notes or transcriptions (Miles and Huberman, 1994). Data display is an organized, compressed assembly of information that permits conclusion drawing and action, (Miles and Huberman, 1994). Looking at displays helps us to understand about the content and to do something either analyze further or take action based on that understanding. Verification may be as brief as a fleeting second thought crossing the analyst's mind during writing, with a short excursion back to the field notes, or it may be thorough and elaborate, with lengthy argumentation and review among colleagues to develop "inter subjective consensus," or with extensive efforts to replicate a finding in another data set (Miles and Huberman, 1994).

Results of study documents, interviews and observations, can be compared to find out the conclusion. In this research, the results of documents analysis and classroom observation are converted to show the percentage of the performance in the preparing and implementing the authentic assessment.

$$
\text { Indicator's Score }=\frac{\text { Total answer 'ya' }}{\text { Indicator's evaluation }} \times 100 \%
$$

Table 1. Teacher's Conformity Percentage

\begin{tabular}{cc}
\hline Percentage Range & Conformity \\
\hline $80 \%<\mathrm{X} \leq 100 \%$ & Excellent \\
$60 \%<\mathrm{X} \leq 80 \%$ & Good \\
$40 \%<\mathrm{X} \leq 60 \%$ & Sufficient \\
$20 \%<\mathrm{X} \leq 40 \%$ & Poor \\
$0 \%<\mathrm{X} \leq 20 \%$ & Deviate \\
\hline
\end{tabular}

(modified from Peraturan Menteri Pendidikan Nasional No. 35 Tahun 2010) 


\section{Findings and Discussion}

\section{Analysis of Teachers' Authentic Assessment Preparation}

Based on the analysis of teachers' lesson plans can be seen that the authentic assessments on the lesson plans were in accordance with the syllabus. Teachers already included the authentic assessments demanded in the syllabus which are assessment of KI-1 and KI-2 which are attitudes, KI-3 which is knowledge, and KI-4 which is skills of the students. Besides, all teachers already described the technique and instrument of assessment in the lesson plans.

All lesson plans made by those teachers were only using journal technique to assess the students' attitude. The journal was filled with record of the students' attendance, students' activities, and record of the students' behavior. Attitude assessment used observation, self-assessment, and peer-assessment technique was not mentioned by the teachers.

Preparation of knowledge assessment made by teachers in lesson plans of English language learning had been able to quantify the students' knowledge. It can be seen from all lesson plans made for English language learning included written test and worksheet technique to assess the students' knowledge which is in accordance with the syllabus. Observation technique was not mentioned in the lesson plans.

Preparation of skills assessment made in lesson plan by teachers in learning English had been measuring the student skills. In lesson plan, skills assessments made by teachers were in the form of performance assessment and written assessment. Meanwhile, portfolio, product, and project assessment were not included in the lesson plans. The performance assessments used by the teachers were in the form of speaking task for all lesson plans.

Assessment instruments designed in lesson plans were in accordance to assessment technique. Note of the students' attendance, activities of the students, and record of the students' behavior were appropriate with journal assessment technique to assess the students' attitude. Filling monolog/dialogue, answering questions, matching pictures, and making description in the lesson plans were accordance with written test and worksheet techniques used to measure the students' knowledge. Speaking task in the form of describing animal or someone and presenting dialogue were appropriate with the performance assessment technique. Writing a description about animal or someone was appropriate with the written assessment technique.

Follow-up assessments in the lesson plan are usually remedial programs for the students whose achievement of competence under the thoroughness and enrichment program for the students who achieved mastering of each competence. Based on the document analysis for all authentic assessments preparation in lesson plans of English learning made by those three teachers, there was no follow-up assessment prepared by the teachers. Each lesson plans used by teachers did not mention any remedial and enrichment programs.

Authentic assessments preparation in the lesson plans of learning English already included scoring guidelines. Each assessment instruments for knowledge and skills were included with assessment criteria, assessment scale, and scoring rubric. For the attitude assessment that using journal, the content was about the note of the students' behavior and also the students' attendance.

Based on the documents analysis, the percentage of the conformity of the authentic assessment preparation is $53.97 \%$. This result shows that the authentic assessment preparation of grade seven teachers in SMP Negeri 4 Singaraja is in the category of sufficient. However, authentic assessment preparation of grade seven in SMP Negeri 4 Singaraja already meets with the demand of Curriculum 2013. The assessments listed in the lesson plans have met the criteria of authentic assessment according to Peraturan Menteri Pendidikan dan Kebudayaan No. 103 Tahun 2014 about Learning in Primary Education and Secondary Education and Peraturan Menteri Pendidikan dan Kebudayaan No. 104 Tahun 2014 about Assessment of Learning Outcomes by Educator on Primary Education and Secondary Education which are authentic assessment to assess the students' attitudes, knowledge, and skill. Meanwhile, there are some authentic assessments techniques which are not included and developed by teachers in lesson plans.

The authentic assessments prepared by the teachers in the lesson plans already assess the Curriculum 2013 assessment aspects which are attitude, knowledge and skill. All subject teachers only use journal technique to measure competence of attitude. Meanwhile the observation, self-assessment and peer assessment techniques are not prepared by the teachers. In assessing competence of knowledge, those teachers prepare written test and worksheet techniques. Only observation technique is not prepared by the teachers. Performance and written assessment techniques are used to assess students' skills. The teachers did not prepare project, product, and portfolio techniques to assess students' skill. Authentic assessment techniques prepared by the teachers are in accordance with the aspects that would 
be assessed. In the lesson plans made by teachers, journal technique had been appropriate to measure the value of the attitude of students both on KI-1 and KI-2. Worksheet and written test prepared by teachers have been appropriate to measure a students' knowledge. Meanwhile, performance assessment and writing assessment have been appropriate to assess the skill of students. These are consistent with the types of authentic assessments techniques used in Curriculum 2013 according to Peraturan Menteri Pendidikan dan Kebudayaan No. 104 Tahun 2014 which is mentioning educators assess attitude competence through observation, self-assessment, peer assessment by learners, and journals; knowledge competence assess through written tests, observation, and assignments; and educators assess competency skills require learners to demonstrate a certain competence by using performance, project, product, portfolio, and written assessments.

Assessment instruments designed in lesson plans are in accordance to assessment technique. Note of students' attendance, activities of the students, and record of students' behavior are appropriate with journal assessment technique to assess students' attitude. Filling monolog/dialogue, answering questions, matching pictures, and made description in the lesson plans are in accordance with written test and worksheet techniques used to measure the students' knowledge. Speaking task in the form of describing animal or someone and presenting dialogue are appropriate with the performance assessment technique. Writing a description about animal or someone was appropriate with the written assessment technique. This is confirmed in Peraturan Menteri Pendidikan dan Kebudayaan No. 103 Tahun 2014 which stated the assessments system must be adapted based on learning experience gained in the learning process. Peraturan Menteri Pendidikan dan Kebudayaan No. 104 Tahun 2014 also mention authentic assessment is a form of assessment that requires students to show attitude, using the knowledge and skills gained from learning conducted in actual situation. In line with this, Muslich (2010) states that authentic assessment is a comprehensive assessment conducted to assess the start of input, process and output of learning that includes the realm of attitudes, knowledge, and skill.

The results of the assessments obtained by the teachers need follow-up activity to increase the ability of learners and learning improvement. However, there is no follow-up assessment prepared by the teachers. Each lesson plans that used by teachers do not mention any remedial and enrichment programs. This quite serious problem because Peraturan Menteri Pendidikan dan Kebudayaan No. 103 Tahun 2014 mention that the important things to consider in designing assessment according to the Curriculum 2013 is follow-up in the improvement for the next learning process, remedial programs for students whose achievement of competence under the thoroughness and enrichment program for students who have met completeness.

\section{Analysis of Teachers' Authentic Assessment Implementation}

Based on the classroom observations, the teachers always gave reinforcement on any lessons. Choices of the most frequently performed by teachers were in the form of praise and motivational phrases to students who were able to perform the task well or who were still lacking in the lesson. Appreciation with applause was also conducted by teachers with the students to motivate all students in the learning process. The teachers also gave warning to some students who often made a fuss during learning.

Attitudes assessment held by the teachers already included assessment of spiritual and social attitudes. These attitudes assessments were done by the teachers when the learning process started, students made a discussion in learning, and at the end of the lesson. Technique used by the teachers in conducting attitudes assessment was journal. The researcher conducts six times of classroom observation in two weeks. Journals techniques were used by all subject teachers in every meeting.

Journals were usually filled by the teachers at the end of the lesson. The journals were contained of student attendance, list of activities in the class room, and materials that have been thought. The teacher also toke a note in the journal for the students' attitude in the classroom such as good and bad behavior done by the students in the learning process.

Authentic assessment in aspects of knowledge was done by those subject teachers during the learning process. Authentic assessments of knowledge were done by the teachers by using technique of written tests, observation, and worksheet. Written test, observation, and worksheet were given after the material delivered by the teachers to assess the students' knowledge. The written tests given by the teachers in the classroom observation were in the form of listening and writing task. For the worksheet were in the form of writing task.

Teachers had conducted the authentic assessment of students' skills competency in English learning. The authentic assessments implemented by teachers were in the form of performance and written assessment accordance to the lesson plans of learning. Meanwhile, assessments of project, product, and portfolio were not used by the teachers in learning process. 
In the classroom observation of authentic assessments implementation in English teaching done by the teachers, there was no follow-up assessment implemented by the teachers. Those teachers did not mention any remedial and enrichment programs in the learning process.

Based on the description of data observation of authentic assessment implementation, it can be concluded that the percentage of the conformity of the authentic assessment preparation is $44.4 \%$. This result shows that the authentic assessment implementation of grade seven teachers in SMP Negeri 4 Singaraja is in the category of sufficient. However, implementation of authentic assessments based on the lesson plans made already conformed to Peraturan Menteri Pendidikan dan Kebudayaan No. 103 Tahun 2014 about Learning in Primary Education and Secondary Education and Peraturan Menteri Pendidikan dan Kebudayaan No. 104 Tahun 2014 about Assessment of Learning Outcomes by Educator on Primary Education and Secondary Education. Attitudes, skills, and knowledge assessments had been implemented very well by teachers. Despite there are several authentic assessments undertaken by teachers which are not included in the lesson plans.

Assessment of attitudes is done by teachers using journal technique starting from the lesson began until the learning process happen. While at the end of the activity, the teachers filled out daily journals related to activities that involve the students in the learning process. The journals are contained of student attendance, list of activities in the class room, and materials that have been thought. The teachers also take a note in the journal for the students attitude in the classroom such as good and bad behavior that done by the students in the learning process.These are in accordance to Peraturan Menteri Pendidikan dan Kebudayaan No. 104 Tahun 2014 about Assessment of Learning Outcomes by Educator on Primary Education and Secondary Education, which mention the types of authentic assessments used to asses students' attitude are observation, self-assessment, peer-assessment by learners, and journals. Journal is record of teacher/educator note in the school about students' attitude and behavior in entire learning process.

Authentic assessments of knowledge that teachers used during English learning are written tests and worksheet. These authentic assessments have been prepared before in the lesson plans and those are implemented as well as been mentioned in the lesson plans. The written tests are in the form of translating, completing some sentences, completing dialogue, and matching picture. The worksheets are given in the form of making some sentence, exercise from students' handbook, and make a description or dialogue. Observation technique which is not mentioned in the lesson plans, also conducted in the learning process. The observation is done during the learning process by directly asking some questions to the students about the learning material given.This is confirmed by statement of Peraturan Menteri Pendidikan dan Kebudayaan No. 104 Tahun 2014 about Assessment of Learning Outcomes by Educator on Primary Education and Secondary Education which states authentic assessment in the implementation of the curriculum in 2013 refers to the assessment standards consist of knowledge through written tests, observation, and worksheet. Written test given at the end of each lesson the teachers as the evaluation of learning that has been done. Observations carried out by teachers when the students had a discussion regarding the material given in the learning process. While the worksheet given and teachers are usually taken from the book to make by students individually or in groups.

Authentic assessments of skill have been done by teachers during the learning process. On English language learning, authentic assessments of skill has been carried out by teachers through performance and written assessment techniques. The performance assessment is in the form of presenting a description or performing a dialogue. The written assessment given is in the form of writing a simple description and making a dialogue. These is in accordance with the contents Peraturan Menteri Pendidikan dan Kebudayaan No. 104 Tahun 2014 about Assessment of Learning Outcomes by Educator on Primary Education and Secondary Education also suggested a skills competency assessment can be conducted using performance assessment, project assessment, product assessment, portfolios, and written assessment.

Based on the classroom observation of authentic assessments implementation in English learning done by those three teachers, there is no follow-up assessment implemented by the teachers. Those teachers do not mention any remedial and enrichment programs. However, based on short interview after the observation with all the teachers, they mentioned that remedial and enrichment program are usually given after daily test which is an activity performed periodically to assess the competence of learners after completing one or more basic competency. Besides, remedial and enrichment program are also given after midterm and end semester test. Meanwhile, in all classroom observation, the subject teachers always give reinforcement during the learning process in the form of praise, motivational phrases, and applause to motivate the students. These activities are confirm by Peraturan Menteri Pendidikan dan Kebudayaan No. 103 Tahun 2014 which mentions teachers have to plan follow-up activities in term of providing positive feedback, reinforcement, enrichment, and remedial based on the students' learning outcomes. 


\section{Analysis of Teachers' Authentic Assessments Obstacles}

Based on the interview with the subject teacher, the obstacles experienced by teachers in the preparation of authentic assessments are not too significant. It is caused by the existing guidelines on the teachers' handbook. However, a new teacher in SMP Negeri 4 Singaraja found obstacle in terms of adjusting the assessment given to the students with their competency. The obstacles encountered during the implementation of authentic assessments by those teachers in the implementation of authentic assessments are on the number of students and lack of time to finish the assessment. The large number of the students made the process of assessment became quite difficult for the teachers.

Solutions that have been made by the teachers to overcome the obstacles experienced in the implementation of authentic assessment are to organize well all learning activities undertaken such as firmness to the students about finishing the assessment on time, giving a warning for the students who disturbing the learning process and extra task to educate them, or extra point to motivate students in learning. In addition, exchanging experiences with colleagues is also the way to overcome the obstacles encountered during the conduct authentic assessment. In Peraturan Menteri Pendidikan dan Kebudayaan No. 103 Tahun 2014 has been explained that the development of lesson plan by teachers can be conducted independently or together through consultation with other teachers in a particular school and supervised by the principal or senior teachers appointed by the school principal.

\section{Conclusions}

Based on the findings of research and discussion, it can be summarized that the percentage of the conformity of authentic assessment preparation based on Curriculum 2013 by the teachers of grade seven in SMP Negeri 4 Singaraja is $53.97 \%$ which category is sufficient. Each lesson plans created already include authentic assessments, i.e. authentic assessments of attitudes, knowledge and skills which is in accordance to the demand of on Peraturan Menteri Pendidikan dan Kebudayaan No. 103 Tahun 2014 and Peraturan Menteri Pendidikan dan Kebudayaan No. 104 Tahun 2014. However, not all types of authentic assessment techniques are designed and developed in the lesson plans. In the implementation, the percentage of the conformity of authentic assessment by the teachers of grade seven in SMP Negeri 4 Singaraja is $44.4 \%$ which category is sufficient. The implementation of authentic assessments are carried out based on the teacher preparations in lesson plans and also some addition of authentic assessment techniques are implemented by the teachers in the learning process. Authentic assessments have been capable already to measure the competence of knowledge, attitudes and skills of the students which is accordance to the demand of on Peraturan Menteri Pendidikan dan Kebudayaan No. 103 Tahun 2014 and Peraturan Menteri Pendidikan dan Kebudayaan No. 104 Tahun 2014. Although the preparation and implementation of authentic assessments run well, there are still obstacles experienced by teacher in terms of the large number of students and lack of time to finish the assessment. The large number of students made the process of assessment became quite difficult.

\section{Acknowledgement}

The author wishes to acknowledge the principal and the teachers in SMP Negeri 4 Singaraja who had supported the writers when conducting the research. The author also wishes to acknowledge the support of colleagues and all those people who participate this study.

\section{References}

Aliningsih, F., \& Sofwan, A. (2015). English Teachers' Perceptions and Practices of Authentic Assessment. Language Circle: Journal of Language and Literature, 10(1), 19-27. Retrieved from: http://journal.unnes.ac.id

Fatonah,S., Suyata, P., \& Prasetyo, Z. K. (2013). Developing an Authentic Assessment Model in Elementary School Science Teaching. Journal of Education and Practice, 4(13), 50-61. Retrieved from: http://www.iiste.org/Journals/index.php/JEP/article/download/6774/6887

Idham. F. I., Nadrun, \& Darmawan (2015). The Use of Authentic Assessment in English Writing Skill to the Eleventh Grade Students. e-Journal of English Language Teaching Society (ELTS, 3(1), 1-13. Retrieved from: http://jurnal.untad.ac.id/jurnal/index.php/ELTS/article/view/4401/3279 
Menteri Pendidikan dan Kebudayaan. (2013). Peraturan Menteri Pendidikan dan Kebudayaan No. 65 Tahun 2013 tentang Standar Proses Pendidikan Dasar dan Menengah. Jakarta: Kementerian Pendidikan dan Kebudayaan.

Menteri Pendidikan dan Kebudayaan. (2014). Peraturan Menteri Pendidikan dan Kebudayaan Nomor 103 tahun 2014 tentang Pembelajaran pada Pendidikan Dasar dan Menengah. Jakarta: Kementerian Pendidikan dan Kebudayaan.

Menteri Pendidikan dan Kebudayaan. (2014). Peraturan Menteri Pendidikan dan Kebudayaan Nomor 104 tahun 2014 tentang Penilaian Hasil Belajar oleh Pendidik pada Pendidikan Dasar dan Menengah. Jakarta: Kementerian Pendidikan dan Kebudayaan.

Miles, M. B., \& Huberman, A. M. (1994). Qualitative Data Analysis. 2nd Edition. Thousand Oaks, California: SAGE Publication.

Mueller, J. (2005). The Authentic Assessment Toolbox: Enhancing Student Learning through Online Faculty Development. Retrieved from: http://jolt.merlot.org/documents/vol1no1mueller001.pdf

Nesari, A.J., \& Heidari, M. (2014). The Important Role of Lesson Plan on Educational Achievement of Iranian EFL Teachers' Attitudes. International Journal of Foreign Language Teaching \& Research, 3(5), 25-31. Retrieved from: http://jfl.iaun.ac.ir/article_10884_43a5ff2bb7fbd6998f091eb726f80104.pdf

Syofiana, M. (2010). Autentik Asesmen. Available at: http://sofya6.blogspot.co.id/2010/11/autentikasesmen.html 